\title{
Gaining Voluntary Tax Compliance through Social Media Influencers: a Descriptive Analysis of the Meaning of Hashtag Usage \#PajakProfesi on Instagram Account of Directorate General of Taxes
}

\author{
N. Risdiana ${ }^{1}$, P. Utari' ${ }^{2}$ I.A. Satyawan ${ }^{3}$ \\ ${ }^{1}$ Master of Communication Study Program, Faculty of Social and Political Sciences, Sebelas Maret \\ University, Surakarta, Indonesia, ${ }^{2}$ Departement of Communication Science, Faculty of Social and \\ Political Sciences, Sebelas Maret University, Surakarta, Indonesia, ${ }^{3}$ Departement of Communication \\ Science and International Relations, Faculty of Social and Political Sciences, Sebelas Maret University, \\ Surakarta, Indonesia \\ ${ }^{1}$ nitarisdiana@student.uns.ac.id, ${ }^{2}$ prahastiwi@staff.uns.ac.id, ${ }^{3}$ agungsatyawan@staff.uns.ac.id
}

\begin{abstract}
Taxpayer compliance is not only influenced by the rule of law but also by social factors. Directorate General of Taxes (DGT) starts to take influencers to undergo taxation socialization through hashtag \#PajakProfesi on Instagram of DGT. This descriptive phenomenology research wants to examine the meaning of social media influencer on hashtag usage \#PajakProfesi on instagram account of DGT. Meanwhile, technique of collecting data was conducted by interview and online data observation. The research finding showed that the influencers and hashtag usage have meaning of activator and social change. Hashtag defined as a way to compile information to ease social media users in finding out the information. Famous figures having symbol as influencer in their community are able to encourage other people to understand and obey the tax regulation. However, influencers as social dimension do not inevitably increase tax compliance directly; there are many aspects which must be considered by taxpayer.
\end{abstract}

Keywords: taxpayer's compliance, influencers, social media socialization, hashtag usage

\section{Introduction}

Nowadays, modern tax system in the world generally used to fulfill community collective need, and used as a method to redistribute wealth and reduce poverty among other economic and social problems [1]. Tax revenues in Indonesia accounted for more than $83 \%$ of total revenues of state budget in 2020 [2]. Indonesia has changed its tax collection system from Official Assessment changed into Self Assessment, since amendment of the provisions of tax legislation in 1983 (Indonesian tax reform) to replace taxation regulation created by Dutch Colonial [3]. The taxpayers are given the trust to calculate, take into account, pay, and report by themselves the amount of tax that should be owed based on the tax legislation. Indonesian taxpayers compliance level divided to two types; material compliance and formal compliance. Formal compliance is taxpayer compliance in reporting year notification letter (SPT), while material compliance is taxpayer compliance in revealing the actual amount of income obtained by the taxpayer [4] Therefore, the aspect of voluntary tax compliance is very important, so the target of tax revenue can be achieved.

In particular, Devos [1] researched three variables, which have potential to influence compliance behavior of the taxpayer, they are; tax morale, tax equity/fairness, and deterrence 
measures. Tax morale is related to beliefs and norms of the taxpayer related to their tax obligation. Tax equity/fairness refers to taxpayer's point of view to whole regulation of taxation system. Deterrence measures associated with imposition of fines with law enforcement and probability detection. Especially for tax fairness, it is very important to be understood because it can influence individual willingness to consider the government as trustable party, hence it can prevent tax deterrence behavior and encourage cooperative behavior. Three primary dimensions comprising the construct of tax fairness are fairness of the tax assessment process, exchange equity, and vertical equity [5].

Technology development also provides changes in how to socialize tax regulation. The existence of social media as a medium of communication, which is more public, becomes one of the ways to build engagement with taxpayers. Social media refers to internet based application which possible to allows communication among users, and various contents created by social media users [6], [7]. Social media has ability to allow the users either to represent themselves or interacting, cooperating, sharing, communicating with other users, and virtually forming social bond which affects informal interaction, institutional structure and professional routines, and it can change the conditions and rules of social interaction [8], [9]. As much information presented through social media, there are many users use social media to collect information regarding to decision making [10]. Yet, the research which is about social media impact as factor that influences taxpayer compliance behavior seems not much to be conducted yet.

One of the most interested social media is Instagram which has a higher user growth rate compared to other social media. In June 2018, Instagram officially announced that they have had one billion users from all over the world, it snappily jumped from September 2017 in which Instagram only has 800 million users [11]. From total population of 264 million people of Indonesia, there are 171.17 million or about $64.8 \%$ people which have been connected to internet. Moreover, for 61.61 million or about $22.6 \%$ people in Indonesia are the user of Instagram [12], [13]. Furthermore, due to many internet users who used Instagram as social media platform, it is interesting to conduct research about taxation socialization in Instagram employing certain figures as influencer.

Social media has function as public space where the user is able to be influencer through symbolic interaction which he built. Three main principals of symbolic interactions relating to meaning, language, and thought which refer to the conclusion concerning self-creation and individual socialization in the larger society which is created and defined through interactions history in a person's social world. People will interpret themselves and the message of the stimulus that we provided through the symbols in interacting, so they give responses to our actions, and the formation of identity is also strongly influenced by social media through the content that is displayed [14]. High reciprocal level happened on the social media relating to symbolic meaning, included meaning of building social relationship and personal image which are formed by technical features of the media used, and social relationship among the users [15].

Hashtag used as a condensed version of information, which characterizes topics and discussions, can cause change within certain community [16]. Like the hashtag used as a rhetoric tool to voice a discourse in cyberspace, it demands a real movement on an issue to be fought for. The usage of hashtag \#SayHerName, complementing the hashtag \#BlackLivesMatter, was once echoed as a mechanism to get media attention and allow the campaign to grow beyond moral outrage and resistance about black women, mothers, and victims of police brutality both now and in the past [17]. Changes in political practices and the 
media system for the following years have increased the urgency to critique the ongoing social order [18].

DGT also innovates actively on the @ditjenpajakri Instagram account, that motivated by the rapid development of the internet to promote taxation socialization. DGT take several figures as influencers to introduce tax calculations according to each other's type of work with the hashtag \#PajakProfesi. The influencers are Hotman Paris Hutapea as a lawyer, Deddy Corbuzier as a content creator, Didiet Maulana as a designer, Jonathan Christie as an athlete, Chelsea Elizabeth Islan as an actress, Windy Ariestanty as an author, Didi Kempot as a singer, Arifin Panigoro as a businessman and many more. They are well-known figures in their respective fields of work. The information conveyed in their message is same; it is to invite people to pay the tax, beside the definitions of each work and the way to count the taxes according to the type of work.

Coordinated Management of Meaning (CMM) Theory stated that a person will give a meaning to the situation, behavior, and message of others, then decide how to respond when facing various communication situations. Meaning and action are shaped by constitutive and regulative rules, which are basically rules to interpret a message. Therefore, it is important to achieve and maintain some coordination form involving organizing interpersonal actions to interpret a message [19]. In a message made to achieve the compliance, Marwell and Schmitt required five strategies including reward (i.e. promising), punishment (i.e. threatening), expertise (as displaying knowledge about rewards), impersonal commitment (including moral appeals), and personal commitment (i.e. debt) [19].

\section{Method}

This article is going to discuss about the meaning formed in content preparation with the hashtag \#PajakProfesi in the DGT Instagram account and the meaning of influencers as social dimension related to tax compliance. This research used descriptive qualitative method, which has purpose to comprehend the phenomenon experienced by subject research and describe it into the words [20]. Research strategy used was phenomenology, that emphasizes people's conscious experience of a phenomenon through direct experience and the point of view of each individual [19]. The method of collecting data was consisted of interview, online data observation and literature review. Primary data obtained through interviews were conducted with four respondents who made comments related to the content with the hashtag \#PajakProfesi on the Instagram account @ditjenpajakri. Secondary data was observation and documentation of content with the hashtag \#PajakProfesi, and literature studies which was obtained online. Data validation conducted by performing primary data using information from four respondents who did not know each other but had the characteristics that had been determined to be used as respondents.

\section{Result and Discussion}

The level of tax compliance in Indonesia in 2019 reached $103.47 \%$ of the target which can be seen in figure 1. It can be said that the achievement of Indonesian taxpayer compliance is actually still low, seen from the presentation of taxpayer targets making payments only $51.64 \%$ of the total corporate and non-employee taxpayers. Resistance to make taxes payment, 
non-compliance, or tax evasion, is an indication of individual disappointment with or lack of commitment to the tax system [1]. Therefore, it needs to be reviewed about how DGT socialize the taxation regulation to Indonesian taxpayer.

\begin{tabular}{c|l|c|c|r|}
\hline $\begin{array}{c}\text { Code } \\
\text { SS/IKU }\end{array}$ & \multicolumn{1}{|c|}{$\begin{array}{l}\text { Strategic Target/Key } \\
\text { Performance Indicators }\end{array}$} & Target & Realization & $\begin{array}{l}\text { Perforaance } \\
\text { Index }\end{array}$ \\
\hline \multicolumn{4}{|c|}{ Stakeholder Perspective (25\%) } \\
\hline 1 & Optimal State Tax Rerenue & $21,11 \%$ \\
\hline la-CP & Percentage of tax revenue realization & $100 \%$ & $84,44 \%$ & $84,44 \%$ \\
\hline \multicolumn{4}{|c|}{ Customer Perspective (15\%) } \\
\hline 2 & Excellent public service & $15,54 \%$ \\
\hline 2a-CP & Public satisfaction index for DGTservices & 4,29 & 4,45 & $103,73 \%$ \\
\hline 3 & High taxpayer compliance & $103,47 \%$ \\
\hline 3a-CP & $\begin{array}{l}\text { Percentage of corporate taxpayer compliance } \\
\text { and-private person non employee }\end{array}$ & $60 \%$ & $62,08 \%$ & $103,47 \%$ \\
\hline 3a1-CP & $\begin{array}{l}\text { Percentage of formal compliance level of the } \\
\text { Corporate taxpayer and PP non-employee }\end{array}$ & $70 \%$ & $72,52 \%$ & $103,60 \%$ \\
\hline 3a2-CP & $\begin{array}{l}\text { Presentage of Corporate Taxpayer and PP } \\
\text { Non-Employee who make payments }\end{array}$ & $50 \%$ & $51,64 \%$ & $103,28 \%$ \\
\hline
\end{tabular}

Fig.1. Table of Target and Realization of IKU Ministry of Finance-one DGT of 2019 Source: 2019 DGT Performance Report

So far, tax socialization has been carried out by DGT employees both individually face to face and through tax classes. The counseling material was developed by the Director of Counseling, Services and Public Relations of DGT. It used by all tax offices spread in 34 regional offices, $352 \mathrm{KPP}$, and $204 \mathrm{KP} 2 \mathrm{KP}$ throughout Indonesia [21]. Along with the development of technology, DGT has official social media account in Instagram (a) ditjenpajakri that shares much information regarding taxation in Indonesia. Especially with hashtag \#PajakProfesi, DGT presents famous public figure as symbol of obedient taxpayer, and medium of socialization about how to count the income taxes of certain profession.

For example, Hotman Paris Hutapea, a senior lawyer who is known with nick name 'Raja Pailit', 'Celebrity Lawyers', 'The Most Dangerous Lawyer', and one of Australian magazine called him as 'Bling-bling Lawyer' and also '30 billion lawyer' [22]. Symbol of influencer used was not only verbal symbol including language but also identity symbol and nonverbal symbol including facial expressions and body gestures. Enactment is a process where the meaning of symbol interpreted then it form and influence the response and people's behavior [23]. Regardless of the social media platform where the message is disseminated, corrective action proven as the most interesting strategy which can stimulate more online reaction, such as likes, shares, and positive comment [24]. Those researches support DGT strategy which uses famous figures having reliable professional symbol as influencers to disseminate corrective actions on how to calculate taxes with the hashtag \#PajakProfesi in Instagram account@ditjenpajakri.

Based on the interview, the existence of the social media defined as new medium in socializing the taxation. Recently, various information of taxation is easier to be sought through social media, especially Instagram and Twitter platform. Besides, the society can easily communicate with DGT through conversations on social media. The DGT social media admin is required to provide fast response to every question on social media asked by internet users, regarding the image of the institution as a good government. The content with hashtag 
\#PajakProfesi is interpreted as an example of taxpayer with high level of tax compliance. Famous figures in each profession encourage respondents to have same action. Especially for colleagues who idolize these figures, their willingness to comply the tax regulations will appear. However, the respondent stated that there were difficulties to count the taxes using self-assessment, hence they still need a help from tax officers. Those difficulties caused by the lack of understanding of the taxpayer to types of his received income and used taxes rate. A sense of fairness over tax treatment is also considered as less evenly distributed for some professions regarding the amount of the basic calculation of taxes and taxes rates, so it can cause tax evasion. The lack of understanding of taxation regulations and sense of unfairness of taxes can reduce the level of voluntary tax compliance of taxpayers.

However, the influencer role as social dimension is not felt to be very effective in directly influencing taxes compliance. The research finding of Yuniarta and Purnamawati to taxpayers of small and medium-sized enterprises (SMEs) in Bali Province showed that a money motives (as a psychological concept) and tax socialization (as a social concept), did not significantly influence tax compliance, but Karma Phala (as a spiritual concept) has a significant and positive impact on taxpayer's compliance [25]. The factors influencing taxes compliance of SMEs for income tax reporting requirements in Indonesia included reference groups, the audit probability, tax knowledge, and perceptions of equity and fairness which have significant impact on tax compliance. In particular, the most significant impact to SMEs taxpayer noncompliance behavior is the reference groups [26]. Commitment of taxpayers in the context of tax compliance can play an important role in explaining high levels of compliance, even in conditions of low trust, where there is a perception of unfairness in the tax system or weak relations between taxpayers and tax authorities [27].

The interpretation of the message in the \#PajakProfesi content defined as an obligation to the country to carry out tax obligation obediently. It is in accordance with CMM theory which expressed that the taxpayers shape the meaning of the message based on constitutive and regulative rules. Constitutive rule is where communicators organize behavior and help communicants understand how messages are interpreted. This is reflected in the explanation of the definition of profession and the procedure for calculating professional tax. Regulative rule relates to how communicators give reaction to the message and how they give response or feedback to the message they received that reflects on the comment column. Therefore, with the existence of constitutive and regulative rules, it is expected that taxpayers can interpret the message identically and by influencer affective factors, the taxpayers are expected to commit to having a high level of voluntary compliance.

The message strategy to achieve compliance stated by Marwell and Schmitt, has yet not been fully used in \#PajakProfesi content. Persuasive messages are only written in caption and interpreted as messages originating from DGT, not directly from influencers themselves. Appreciation for taxpayer compliance is reflected in the other Instagram content which is summarized with the hashtag \#pajakkitauntukkita. The punishment has never been discussed either in the hashtag \#PajakProfesi or other contents of the DGT Instagram, where DGT does not want to be seen as a frightening institution, it rather wants to convey positive persuasive messages. Expertise has not been reviewed yet on the hashtag \#PajakProfesi which means that if you comply, you will be rewarded because of the "nature of things". Normally, awards for taxpayers are given annually and shared in each regional office. The impersonal commitment has meaning that you will be immoral if you do not obey the rule and the personal commitments meaning the taxpayer owes everything that is given by the government. Moreover, it is also not discussed in the hashtag \#PajakProfesi. Impersonal and personal 
commitments which refer more to social norms, should be instilled early through the civic education system.

\section{Conclusion}

Influencers and hashtag usages have movement and social change meaning. Famous figures whose have symbol as influencers in their communities are able to encourage the willingness of others to understand and obey tax regulations. However, influencers as social dimension do not inevitably increase tax compliance directly; there are many aspects which must be considered by taxpayer such as tax morale aspect, tax fairness level, preventive measures for tax evasion, spiritual aspects and taxation socialization aspects. DGT should apply the message strategy developed by Marwell and Schmitt to get taxpayer compliance, while still paying attention to the image of a non-frightening government organization.

\section{Acknowledgements}

The author would like to thank the Ministry of Communication and Information Technology for providing scholarships. The author also express sincere gratitude to respondents who are willing to be interviewed so that this research can be carried out.

\section{References}

[1] K. Devos, Factors Influencing Individual Taxpayer Compliance Behaviour. Netherlands: Springer, 2014.

[2] Ministry of Finance, “APBN 2020,” 2020. https://www.kemenkeu.go.id/apbn2020 (accessed Jun. 26, 2020).

[3] Directorate General of Taxes, "Sistem Perpajakan.” https://www.pajak.go.id/id/sistemperpajakan (accessed Jun. 26, 2020).

[4] BPPK Kemenkeu, "Indikator Keberhasilan DJP adalah Tingkat Kepatuhan Wajib Pajak," 2017. https://bppk.kemenkeu.go.id/content/berita/pusdiklat-pajak-indikator-keberhasilan-djp-adalahtingkat-kepatuhan-wajib-pajak-2019-11-05-c429d9d3/ (accessed Jun. 26, 2020).

[5] J. Farrar, D. W. Massey, E. Osecki, and L. Thorne, "Tax Fairness: Conceptual Foundations and Empirical Measurement," J. Bus. Ethics, vol. 162, no. 3, pp. 487-503, 2020, doi: 10.1007/s10551-018-4001-4.

[6] A. Guille, H. Hacid, C. Favre, and D. A. Zighed, "Information diffusion in online social networks: A survey," SIGMOD Rec., vol. 42, no. 2, pp. 17-28, 2013, doi: $10.1145 / 2503792.2503797$.

[7] A. M. Kaplan and M. Haenlein, "Users of the world, unite! The challenges and opportunities of Social Media,” Bus. Horiz., vol. 53, no. 1, pp. 59-68, 2010, doi: 10.1016/j.bushor.2009.09.003.

[8] R. Nasrullah, Komunikasi Antar Budaya di Era Budaya Siber. Jakarta: Kencana Prenada Media Group, 2012.

[9] J. Van Dijck and T. Poell, "Understanding social media logic," Media Commun., vol. 1, no. 1, pp. 2-14, 2013, doi: 10.12924/mac2013.01010002.

[10] L. V. Casaló, C. Flavián, and S. Ibáñez-Sánchez, "Influencers on Instagram: Antecedents and consequences of opinion leadership," J. Bus. Res., no. July, 2018, doi: 
10.1016/j.jbusres.2018.07.005.

[11] A. A. Sendari, "Instagram Adalah Platform Berbagi Foto dan Video, Ini Deretan Fitur Canggihnya," 2019. https://www.liputan6.com/tekno/read/3906736/instagram-adalah-platformberbagi-foto-dan-video-ini-deretan-fitur-canggihnya (accessed Jun. 14, 2020).

[12] Y. Pratomo, “APJII: Jumlah Pengguna Internet di Indonesia Tembus 171 Juta Jiwa.” https://tekno.kompas.com/read/2019/05/16/03260037/apjii-jumlah-pengguna-internet-diindonesia-tembus-171-juta-jiwa (accessed Jun. 14, 2020).

[13] W. K. Pertiwi, "Sebanyak Inikah Jumlah Pengguna Instagram di Indonesia?,” 2019. https://tekno.kompas.com/read/2019/12/23/14020057/sebanyak-inikah-jumlah-penggunainstagram-di-indonesi (accessed Jun. 14, 2020).

[14] E. Griffin, A. Ledbetter, and G. Sparks, A First Look at Communication Theory, 10th ed. New York: Mc-Graw Hill Education, 2019.

[15] R. R. Chen, R. M. Davison, and C. X. Ou, "A symbolic interactionism perspective of using social media for personal and business communication," Int. J. Inf. Manage., vol. 51, no. June 2018, p. 102022, 2020, doi: 10.1016/j.ijinfomgt.2019.10.007.

[16] P. Lorenz-Spreen, F. Wolf, J. Braun, G. Ghoshal, N. Djurdjevac Conrad, and P. Hövel, "Tracking online topics over time: understanding dynamic hashtag communities," Comput. Soc. Networks, vol. 5, no. 1, 2018, doi: 10.1186/s40649-018-0058-6.

[17] J. L. Borda and B. Marshall, "Creating a space to \#SayHerName: Rhetorical stratification in the networked sphere,” Q. J. Speech, vol. 106, no. 2, pp. 133-155, 2020, doi: 10.1080/00335630.2020.1744182.

[18] T. A. Hollihan and J. F. Klumpp, "Rhetorical Criticism as Moral Action Revisited: Moral and Rhetorical Imperatives in a Nation Trumped," West. J. Commun., vol. 84, no. 3, pp. 332-348, 2020, doi: 10.1080/10570314.2019.1704856.

[19] Stephen W. Littlejohn, K. A. Foss, and J. G. Oetzel, Theories of Human Communication, 11th ed. Illinois: Waveland Press-Inc, 2017.

[20] L. J. Moleong, Metodologi Penelitian Kualitatif. Bandung: Remaja Rosdakarya, 2005.

[21] Directorate General of taxes, "1 Oktober 2018, Ditjen Pajak Resmikan 23 Kantor Baru." https://www.pajak.go.id/1-oktober-2018-ditjen-pajak-resmikan-23-kantor-baru\#: :text=Dengan diresmikannya 23 unit kantor,KP2KP di seluruh wilayah Indonesia (accessed Jun. 26, 2020).

[22] G. Abdul, "Eksklusif Hotman Paris Hutapea, Anak Kampung yang Mendunia," 2016. https://www.fimela.com/lifestyle-relationship/read/2455815/eksklusif-hotman-paris-hutapeaanak-kampung-yang-mendunia (accessed Jul. 05, 2020).

[23] P. Gopal, Abhijit.; Prasad, "Understanding GDSS in Symbolic Context: Shifting the Focus from Technology to Interaction," vol. 24, no. 3, pp. 509-546, 2000.

[24] E. Borowski, Y. Chen, and H. Mahmassani, "Social media effects on sustainable mobility opinion diffusion: Model framework and implications for behavior change," Travel Behav. Soc., vol. 19, no. December 2019, pp. 170-183, 2020, doi: 10.1016/j.tbs.2020.01.003.

[25] G. A. Yuniarta and I. G. A. Purnamawati, "Spiritual, psychological and social dimensions of taxpayers compliance," J. Financ. Crime, no. August 2019, 2020, doi: 10.1108/JFC-03-20200045 .

[26] F. Inasius, "Factors Influencing SME Tax Compliance: Evidence from Indonesia," Int. J. Public Adm., vol. 42, no. 5, pp. 367-379, 2019, doi: 10.1080/01900692.2018.1464578.

[27] M. Bornman and J. Wessels, "The role and dimensions of taxpayer commitment in tax compliance behaviour," eJournal Tax Res., vol. 15, no. 3, pp. 506-531, 2017. 